Mr. Alen ZEČEVIĆ

Fakultet humanističkih nauka Univerzitet „Džemal Bijedić “ Mostar

E-mail: zecevic_alen@hotmail.com

Stručni rad/Professional article

UDK/UDC: 94:341.1(497.6 Kakanj)"14/18" Demir E. (049.3)

DOI: https://doi.org/10.52259/historijskipogledi.2021.4.6.382

\title{
Emir Demir, STANOVNIŠTVO KAKNJA U OSMANSKOM PERIODU, Udruženje Kreativni centar za edukaciju i obrazovanje „Spektrum“, Sarajevo 2021, 187 str.
}

Kada se govori o povijesti Kaknja i njegove okoline, nemoguće je ne ustvrditi da do danas nije publikovano niti jedno ozbiljnije znanstveno djelo na temelju kojeg bismo bili u prilici detaljnije osvijetliti povijesni kontekst njegovog razvoja u vrijeme osmanske uprave. $\mathrm{Za}$ mnoge entuzijaste dugi niz godina referentna je bila monografija Kaknja iz 1987. godine, premda ona u znanstvenom pogledu nije predstavljala nikakvo značanije ostvarenje. Izostanak spremnosti i institucionalnog zanimanja da se ovom problemu pristupi isključivo iz povijesnog ugla, imao je za rezultat monografiju u kojoj je period osmanske vlasti na području Kaknja predstavljen u krajnje reduciranoj formi. Knjiga dr. Emira Demira Stanovništvo Kaknja u osmanskom periodu, nastala kao izraz svijesti autora o značaju i neophodnosti znastvenog valoriziranja ovog pitanja, vratila je fokus historiografije na

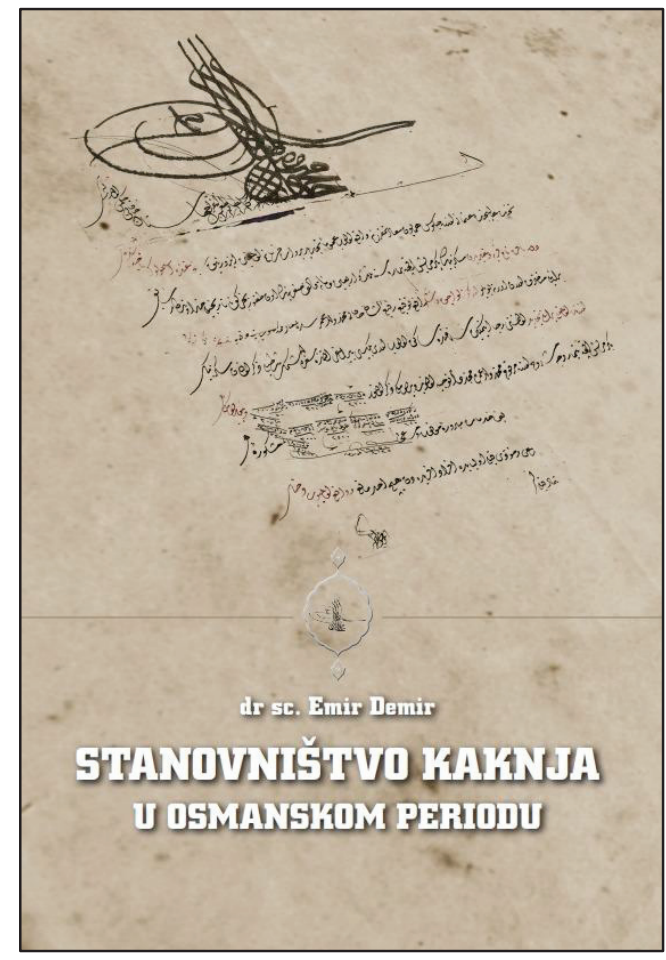
istraživanja prošlosti Kaknja koja je obilježena političkim, kulturnim i vjerskim utjecajima Osmanskog carstva.

Jednogodišnjem istraživanju i nastanku ove izuzetno vrijedne studije prethodio je autorov prevodilački rad na velikom broju dokumenata pisanih na 
osmanskom i turskom jeziku koji su, sa posebnim osvrtom na područje koje danas obuhvata administrativna cjelina općine Kakanj, objedinjeni i publikovani u djelu Popisni defter stanovništva $i$ domaćinstava visočke $i$ zeničke (Brod) nahije za 1266. h. g/1850. godine. Uvidom u sadržaj nepoznate arhivske građe, do koje je došao vršeći selekciju materijala u Odjelu za osmansko naslijeđe Državnog arhiva Republike Turske, dr. Demiru se ukazala prilika da prvobitno utvrđen koncept svog istraživanja redefinira u pravcu proučavanja demografske slike Kaknja i njegove okoline u posljednjim decenijama osmanske uprave. U tom smislu, iz štampe je početkom 2021. godine izašla posve nova knjiga u kojoj su predstavljene informacije o demografskim prilikama u više od 25 naselja i lokaliteta koja gravitiriraju području današnjeg Kaknja.

U metodološkom smislu, izazov interpretacije dokumenata iz 19. stoljeća autor je uspješno premostio analizom i komparacijom njihovih sadržaja sa podacima Sumarnog popisa sandžaka Bosna iz 1468/69. godine, Opširnog popisa Bosanskog sandžaka iz 1604. godine, Popisa timara konjaničkih trupa Pobjedonosne (osmanlijske) vojske za pukovniju (alaj) Bosanskog sandžaka iz 1836. godine, Yoklama (revizornim) defterom namjesnika Bosanskog pašaluka Mehmeda Vedžihi-paše, Popisnog deftera stanovništva i domaćinstava Visočke i Zeničke (Brod) nahije za 1850. godinu: područje današnje općine Kakanj, zatim Yoklama (rezvizornim) defterom Travničkog sandžaka za 1856. godinu i Osmanskim katastarskim registrom za područje Bosne i Hercegovine (od 1866. do 1875. godine). Tumačenjem ovih relevantnih povijesnih izvora i alociranjem sadržaja prevedenih materijala u njima pripadajuće vremenske kontekste, autor je egzaktno potvrdio nekoliko vrlo važnih pretpostavki. Za razliku od popisa iz 15. i 16. stoljeća, iz kojih je moguće izvesti tek zbirne podatke o zakonskim vlasnicima timara i domaćinstvima na naznačenom području, uvidom u Popisni defter za 1850. godinu i usklađivanjem podataka sa natpisima sačuvanih mezara nedvosmisleno su potvrđena lokalna prezimena. Usporedbom sa revizornim defterima, a posebno sa popisima timara, utvrđena su imena stanovnika Kaknja koji su pripadali spahijskom redu.

U tehničkom i vizuelnom pogledu, ova, sadržajem relativno obimna knjiga (187 stranica), upotpunjena je sa 126 fotografskih priloga načinjenih u toku autorovog terenskog istraživanja i obilaska 81 naselja koja su bila predmetom istog. Rasuta po većim i manjim zaseocima, od kojih su pojedina u vidno zapuštenom i ruiniranom stanju, mezarja čuvaju nišane čija se starost može procijeniti na dvjesto ili više godina. Ovi iznimno vrijedni spomenici islamske sakralne kulture, čiji su natpisi pisani arapskim slovima i osmansko-turskim jezikom, za autora su imali jednaku važnost kao i rukopisni izvori arhivskih depoa. Prikupljeni materijal, a riječ je o više od hiljadu kvalitetnih fotografija, stavljen je na raspolaganje budućim istraživanjima.

Posebno značajan aspekt ovog djela ogleda se u činjenici da je riječ o pionirskom pokušaju sistematskog proučavanja migracija stanovništva i genealogije kakanjskih porodica u drugoj polovini 19. stoljeća. Mnoge kakanjske porodice i danas baštine usmene tradicije koje svoje korijene, navodno, imaju u 
poznom bosanskohercegovačkom srednjovjekovlju ili vremenima osmanskih osvajanja ovih prostora. Kao što je to slučaj sa porodicama iz drugih dijelova Bosne i Hercegovine, tako su i pojedine kakanjske porodice u prezimenima očuvale uspomenu na čin, titulu, političku ili vjersku službu koju je obnašao jedan od njihovih dalekih predaka.

Kako se ide dalje i sve dublje u prošlost, a uslijed oskudice relevantnih povijesnih izvora, dokazivanje kontinuiteta ovih prezimena u rasponu od tri ili više stoljeća za znanstvenike će se pokazati kao jedan od najvećih i najsloženijih izazova. Stoga će knjiga dr. Demira, bez sumnje, predstavljati nezaobilazno djelo i jedan od ključnih orijentira kojim će se u svojim budućim istraživanjima isti i rukovoditi. 